\title{
An Exploration on the Professionalization of English Teaching in Higher Vocational Colleges
}

\author{
Rong Dong \\ Jiangxi Technical College of Manufacturing 330095,China
}

Keywords: Higher vocational colleges, English teaching, Professionalization.

\begin{abstract}
It has always been the focus of English teachers in higher vocational colleges that what does English curriculum teach and how. Confronting with current serious employment situation of higher vocational students, English teaching should combine social needs and industry development needs, making teaching professional. This paper firstly analyzes the meaning of professionalization of higher vocational English teaching. Then, with the analysis of related teaching problems, methods to realize English teaching professionalization in higher vocational colleges are proposed.
\end{abstract}

\section{Introduction}

The objective of higher vocational education has been positioned as the cultivation of high-quality and skilled talents, which strongly embodies its "inter-discipline” characteristic. In The Basic Requirements of English Curriculum Teaching of Higher Vocational Education, it is specified that "pay attention to train students' ability to communicate in English", "set up professional English curriculum in combination with professional learning”, "cultivate advanced application-oriented professional talents in fields like technology, production, management, service etc.”, all of which require the professionalization of English teaching. The talent cultivation mode and mission statement determine that English curriculum in higher vocational colleges should be dominated by professionalization and highlight professional application ability. It is of great practical significance to explore the professionalization of higher vocational English teaching.

\section{Meaning of Professionalization of Higher Vocational English Teaching}

It is a fact that the talent cultivation mode in higher vocational colleges is completely different from undergraduate colleges, which lead to the former's confusion of English teaching with professional education, characterizing by professional and practical features. For students of higher vocational colleges, English is not only a curriculum about language knowledge, but also a skill oriented one. Graduates from higher vocational colleges are supposed to possess theoretical knowledge as well as practical operation skills. Thus, higher vocational English teaching should realize professional and practical principles, make professional English as the theme, target the cultivation of oral English and written expression ability, serve the majors and industry of higher vocational colleges, as well as help students' life-long study and professional career development. With the development of economic globalization, the society gradually demands more strictly on the higher vocational talents. So, the English teaching in higher vocational colleges should make their professionalization and practicability more prominent. In addition, the current serious employment situation stimulates higher vocational colleges, which target practical skills training, continually to abide by professionalization-oriented teaching principle, leading English teaching to play a greater value. English teaching in higher vocational colleges, on one hand, aims to enhance students' comprehensive cultural attainment and intercultural communicative ability, on the other hand, focus on the cultivation of English language competence in the workplace environment, guiding students to learn to deal with problems which may be encountered in the future work in English. Besides, with professionalization as the core, English teaching can fully fuse the age characteristic with interests of higher vocational students, which will further highlight its 
practicability and pertinence, as well as enhance students' interest and active in English learning. Therefore, as the teaching guide, teachers are supposed to consider students' own professional characteristics and their future vocational demands in every part of English teaching. Therefore, it can be seem that it is imperative to construct a curriculum system for higher vocational English teaching, in which professionalization works as the core.

\section{Analysis of Higher Vocational English Teaching Problems}

At present, there are many problems in English teaching of higher vocational colleges. Firstly, the teaching goal is vague. For a long time, higher vocational teaching tends to be common-toward, ignoring, in some degree, the characteristics and factual needs of vocational education. There is still a lack of career oriented consciousness and modern vocational education atmosphere in higher vocational English teaching. From teaching plans of some higher vocational colleges, it can be seen that English teaching has not won enough attention and professional English is regarded only as an auxiliary teaching course. The education tends to be examination-oriented, and overlooks the professional training of students. From the English teaching modes of higher vocational colleges, while higher vocational English teaching is continually seeking reform and development, its teaching mode reform is mostly carried out only in conventional aspects like "create a good teaching environment", "enrich teaching methods", "enrich classroom activities", "innovate assessment methods".

The problem of teaching contents homogenization is comparatively serious. In recent years, a series of new English teaching materials of higher vocational colleges have effectively updated those traditional and outdated contents. However, the degree of professionalization still can not meet students' professional English ability needs. No matter the public English teaching or professional English teaching, there are not targeted teaching plans or arrangements. In class teaching, teachers spend most of the time on vocabulary, grammar etc. and there are not enough practice opportunities for students. Although there is professional guidance in English curriculum planning in some higher vocational colleges, it is hard for students to grasp main study points because of the unreasonable curriculum system. At the same time, theoretically, a major is supposed to have a corresponding professional English course, but in fact, due to limited faculty of higher vocational colleges and relatively less practical tasks for part graduates, some English courses are not professional enough, or even no related English courses are set up.

At present, English teaching of a lot of higher vocational colleges still follow the "text centered" mode, in which language knowledge is more stressed and students are in a negative position to receive knowledge. There is no room for the subjectivity of language learning to work. Although many students are capable of passing those application competence tests, they fail to significantly improve the language ability and actual English proficiency, thus it is difficult to meet the career position demands. In addition, English curriculum teaching time is limited at 180-220 lessons that means teachers must complete teaching task and prepare for Public English Test System in a short period of time. So, they have to take the traditional teaching mode, attach more attention to theoretical teaching, be partial to train students' listening, speaking, reading and writing ability, but ignore professional training. On the whole, higher vocational students are at a general low English level, have insufficient daily communicative English application ability and are laborious in English learning. Since those students are relatively weak in English, they are apt to against the traditional indoctrination teaching mode, losing learning enthusiasm as well as initiative. The phenomenon of dumb English has become norm. Since teaching contents are out of line with future career needs, students can not feel the actual value of English learning. Gradually, there is a coping attitude toward English learning, which leads to a low learning efficiency.

Higher vocational colleges aim to cultivate high-quality skilled application-oriented talents which requires their English teachers to be qualified with certain professional skills. However, there are a good many problems existing in current English teaching team. For example, a lack of professional skills, insufficient practical experience in companies since most teachers are graduates without related professional background, deficient comprehensive and systematic understanding of 
professional education, practical teaching experience shortage, inaccurate and unscientific professional English guidance.

\section{Methods to Realize English Teaching Professionalization in Higher Vocational Colleges}

First, for higher vocational colleges, teaching direction should be made clear and for English teachers, the particularity and importance of English teaching need to be deeply realized. In practical teaching, we must insist to target application and practicality, implement the principle of learning in order to practice. Our teaching does not only aim to help students master English application ability, improve the capacity to apply English in real working environment, but also stimulate students' learning potential, arouse English learning initiative, make characteristic of English professionalization outstanding and further demonstrate professional education feature. Specifically, the teaching goal should include the following aspects: firstly, cultivate students' English professional skills and enhance their English professional application ability; secondly, train students' social communicative skills and team cooperation consciousness and ability; lastly, improve students' comprehensive quality and capacity. In line with professional and practical goals and taking students' practical application ability and communicative competence as pretty important priorities, English teaching goal will lay a good foundation for students' career development.

English teaching contents should closely combine with students' majors, highlighting professionalization and application. Oriented by professionalization, English curriculum setting in higher vocational colleges must make its localization and teaching goals explicit, focus on cultivating students' English practical application ability, and fuse professional skills needed in future positions with English curriculum system. The curriculum can be designed as action oriented and base on systematic working process, constructing three practical teaching sectors: English basis, professional application and employment, which will impel the professionalization of teaching contents. In addition, the workplace works as an introduction, with which, the actual English subject needs in positions defines teaching mode. English curriculum construction can be implemented through different disciplines, majors, and phases. Public English courses can be offered at the beginning of the year. Sophomore and junior students accept professional English courses by considering students' professional and position needs. For instance, for students majoring in Automotive Engineering, two Automobile English classes can be set in one week, which will help students master English terminology related to vehicle structure, performance, marketing and so on, as well as guide them to understand cutting-edge vehicle passages and to be capable of smoothly communicating in English with clients. In this way, it will not only assist students in major courses, arouse their learning initiative, but also cultivate gradually professional awareness, build dedicated and competitive consciousness; Electrical Automation English course can include contents like Electric Motor and Electric Motor Control, Electrical and Electronic Technology Fundamentals, etc. Numerical Control Technology English courses should contain Numerical Control Foundation, Numerical Control Lathe, and Employment Situation of Numerical Control etc.

English learning of higher vocational college students aims to be able to communicate and cooperate in English in future positions. In order to make it come true, we need to change the traditional indoctrination teaching mode and flexibly apply various methods to lead students to study actively. For example, the mode which combines task-based approach with communicative approach will arrange students to imitate professional situations in class and provide a good classroom atmosphere for them to have sufficient English communication. With enough practical chances, students will be able to improve their oral expressive and communicative ability. Besides, it is necessary to actively carry out English related activities with task driven teaching approach, with which students are able to enhance their English skills by accomplishing tasks. At the same time, higher vocational colleges should promote cooperation with enterprises, give full play to different teaching environments of school and workplace as well as combine English classroom teaching with practical training. It is also essential to arrange English training in positions. By uniting English training with internship, students will finish English learning tasks during practical training, complete tasks concerning foreign affairs in English and enhance practical problem 
solving ability, realizing "to learn in practice and to practice in learning". Thus, students will realize the importance of English learning to their own career development, then arouse learning initiative and enhance position awareness. In addition, it is certainly needed to enrich extracurricular English activities. Since classroom teaching time is limited and it's not easy for students to take active part in, teachers are supposed to strive to create an English environment, develop the second classroom, and encourage students to participate and practice actively. For instance, let students set up English debate groups, speech groups etc. according to their interests; in order to practice their English application ability, teachers must guide and encourage them take part in oral English contests, writing contests and other English competitions.

Higher vocational colleges should increase manpower reserves and improve the quality of faculty. English subject especially demands more strictly on teachers' professional degree and skills. Higher vocational colleges are encouraged to construct "double qualified" teaching team which is completely different from the traditional "only academic credentials" employment mechanism. Colleges can employ more English talents with rich experience from enterprises as part-time English teachers to enrich English faculty hierarchy structure; at the same time, higher vocational colleges can organize English teachers to specialized enterprises or companies to do practical research or even take a temporary post. This will strengthen their professional skills and impel them to master professional background in society as well as professional status which will further turn English teachers to be "double qualified" from "single qualified". Moreover, colleges need to offer more chances to professional English teachers and public English teachers for communication and discussion. This will help teachers strengthen their study on teaching idea and teaching mode, carry out a detailed analysis on professional teaching problems and promote English teaching professionalization.

\section{Conclusion}

In a word, the professionalization of higher vocational English teaching is an inevitable requirement of higher vocational education to the development of our times. Confronting with new teaching goals, higher vocational colleges should consistently improve, adjust and renovate teaching idea, consummate teaching contents and innovate teaching methods. In this way, it is available to construct a professional English teaching system in higher vocational colleges, accelerate English curriculum to develop toward vocational application, make higher vocational English teaching more practical and targeted, and further lay a more solid foundation for students' career development.

\section{References}

[1]Cheng Chuanxiong. Professionalism and professionalization: an exploration on liberal education methods of higher vocational colleges-take business English major as an example [J]. Education Review, 2016(12): 42-45.

[2]Sheng Lin, Cheng Tingting. Problems and countermeasures of professionalization of higher vocational English education [J]. Modern Educational Practice and Teaching Research, 2016(1): 23.

[3]Liu qiong. A shallow discussion on problems of professionalization of higher vocational English teaching [J]. Journal of Xingtai Polytechnic College, 2011(1): 9-11.

[4]Chen Shaohua. Optimization of professional English teaching in higher vocational colleges [J]. Intelligence, 2013(12): 81.

[5]Chen Keni. Evidences of professionalization trend of higher vocational English teaching [J]. Journal of Qingyuan Polytechnic College, 2012 (4): 81-83. 